\title{
U.S. College Students' Evaluations of Teaching and Its Light on Chinese Higher Education
}

\author{
Ya-zhen $\mathrm{Li}^{1}$, Hong-li Yao ${ }^{2}$ \\ ${ }^{1}$ College of Economics and Management Zhejiang University of Technology Hangzhou, Zhejiang Province, China \\ ${ }^{2}$ College of Foreign Languages Zhejiang University of Technology Hangzhou, Zhejiang Province, China \\ hzlyz@zjut.edu.cn, ellenhl@163.com
}

\begin{abstract}
Students' evaluations of teaching (SETs) are rather popular and fairly matured in the U.S. higher education institutions, which have been equipped with an objective and reliable management system. This paper aims to explore the practice of SETs in U.S. colleges. Through comparative analysis, the paper tries to shed some light on the SETs in Chinese Higher Education from three perspectives, namely, rationale, method and management system. Finally, the research finds that Chinese colleges may learn from U.S. SETs from the following aspects: First, U.S. colleges have general educational goals; second, U.S. SETs emphasize on teachers' professional ethics and character; third, the independence and objectiveness of U.S. SETs are ensured by a third-party agency; fourth, there is a multi-dimensional and student-centered evaluation criteria system in the U.S. SETs.
\end{abstract}

Index Terms - Students' evaluations of teaching, U.S. colleges, Teaching quality

\section{Introduction}

As modern higher education develops, student education, science research and social service have become three major missions of higher education institutions, among which student education takes the center. As a matter of fact, student education and cultural heritage inheritance have always been regarded as the core missions of college ever since its birth. In today's knowledge economy, how to turn out large numbers of high quality human resources has become the key to promoting national competitiveness, enhancing social progress and relaying cultural heritage. In America, teaching constitutes the core part of college faculty's responsibility either in research universities or in non-research universities. Derek Bok noted that according to the statistics from U.S. higher education, the average amount of time spent on teaching-related affairs for each teacher takes more than $50 \%$, while that spent on science research is only less than $20 \%$. Those who claim to engage in teaching far outnumber those in research. In fact, those who publish an essay per year on average are no more than $50 \%$ of all the professors [1]. At the same time, U.S. colleges take teaching performance and quality as a major criterion on teacher evaluation, teacher promotion and the granting of tenure.

As an important method of monitoring teaching quality in higher education, students' evaluations of teaching (SETs) allows students to evaluate teacher effectiveness in classroom teaching based on a set of rating criteria and forms. Since students are the recipients of teaching - the direct receiver of teachers' work, they are the best qualified to speak on teaching quality and their evaluations are more persuasive than any others'. U.S. university administrators hold the opinion that students are the direct receiver of teaching and they have worthwhile opinions on teaching quality, therefore their opinions should be taken into consideration [2]. SETs can promote both teaching and learning, help teachers revise and improve teaching methods and also provide first-hand statistical proof for schools to improve education quality and management. However, there has long been a heated discussion on how to conduct SETs in a scientific way in Chinese higher education institutions. For, in practice, SETs in China seem either to lack credibility or to be reduced to a mere formality, which can't truthfully reflect teachers' work and effectiveness. If such a situation continues, it is bound to have detrimental effect on teaching quality and student education, which calls our close attention to the issue.

\section{An Overview on U.S. College Students' Evaluations of Teaching}

U.S. colleges put a strong emphasis on SETs, which is regarded as an effective measure to evaluate college teaching effectiveness and to manage faculty. From 1920s till now, SET has been established as a policy as well as a routine in U.S. college administration. Therefore, the practice of U.S. SETs is worth to be considered and drawn upon.

Firstly, the clearly defined educational goals of U.S. colleges are the foundation of conducting SETs. Though it seems to be a small link in school education, SET in fact is the direct feedback of consumers to the work effectiveness of producers of educational products, reflecting the extent of the fulfillment of general educational goals. Therefore, the prerequisite of SET is to have a set of clear educational goals, which should be the common objectives of both teaching and learning. It's worth considering what educational goals should be conferred on college. The general educational goals and objectives of U.S. colleges are: the ability to clearly and appropriately communicate in writing and speaking; the ability to think critically by applying logics and mathematical reasoning; to raise students' moral sense; to cultivate students' sense of citizenship; to enhance qualities of adapting to multicultures and globalization; to arouse extensive academic interests in students; to promote employment competence [1]. Clearly defined and meaningful general educational goals not only provide solid criteria and directions for SETs in higher education institutions but also are helpful for school teaching 
affairs administrations to build up scientific systems of specialized courses and objectives. In America, quite a number of universities like Harvard offer a curriculum system that combines both the depth and breadth of knowledge. In such curriculum systems, students' major studies lead to the depth of their knowledge construction, while they also need to select two to three courses in other different fields like humanities, social sciences or natural sciences to broaden their knowledge construction [1]. The "depth and breadth combined curriculum" model continues to develop in U.S. colleges through, for instance, setting "appointed optional courses", "introductory courses" and "classics courses" etc. to ensure that students have a basic knowledge of national and the world cultural heritage. In addition, interdisciplinary courses have also been developed, which are concerned with social problems, such as environmental problems, racial or ethnic problems, globalization and multi-cultural problems etc. to broaden students' horizons.

Secondly, the U.S. SETs are operated by specialized education evaluation agencies to ensure objectiveness and fairness, so as to be adopted as important criteria for teacher promotion etc. First of all, the rating questionnaires are designed by experts of specialized evaluation agencies instead of by the schools themselves, which are based on modern educational rationale and also effective and easy to conduct. Those questionnaires have included the common factors influencing the teaching effectiveness of different types of course, therefore, are suitable for different courses, grades, majors and schools. The data analysis of the outcomes of the questionnaires will be sent back to students through appropriate means.

Due to the objectiveness and fairness of the questionnaires, such SETs are widely recognized by both students and teachers. Since 1990s, many research universities have taken SETs into account in teachers' hiring, promotion, granting of tenure, annual salary rise and so on. Newly recruited faculty will be informed that if they don't have any records of teaching effectiveness and students feedback, they won't get promotion or tenure. Brown University requires teaching quality evaluation in the annual evaluation of teachers' performance and gives it the same importance as research achievements. In the University of Iowa, teachers who want to get promotions or tenure are required to submit an evaluation of practical teaching by both students and colleagues rather than general briefs [4].

The results of SET can help students choose teachers and courses that they really like. Harvard University and Massachusetts Institute of Technology publish their Course Evaluation Guide for all the faculty and students to refer to.

Thirdly, the student-centered multi-dimensional evaluating criteria system ensures the validity of evaluation.

The U.S. SETs are student-centered, which adopt systematic assessment scale equipped with comprehensive and multi-dimensional student evaluation criteria system, so as to evaluate the effectiveness of teaching. Since U.S. College SETs started in the 1920 s and grew into maturity in the 1980 s, a fairly large number of increasingly mature findings have been produced. Professor Kenneth A, Feldman of New York University has long been focused on how to make use of student information to evaluate college teachers and teaching. He once conducted an empirical experiment on "the student evaluation of their teachers' attitudes, conduct and effective teaching practice", which found a list of the most important student-approved characteristics of effective teaching as following: respect and care for students; teachers' knowledge of subject matters; to arouse students' interest; being ready to help; encouraging questioning and discussion; the clarity and comprehensibility of instruction; teaching enthusiasm; lesson preparation and class management; fairness and justice; sensitive notice of students' progress; challenging students' intelligence and ability etc. [5].

In short, the criteria of the U.S. College SETs put emphasis on three aspects: first, teachers' professional ethics and character which include teaching enthusiasm, respect and care for students and being ready to help. Second, teachers' professional quality, that is, teachers' knowledge of subject matters. Third, teachers' professional competence which includes stimulating students' interest, the clarity and comprehensibility of instruction, lesson preparation and class management, and encouraging questioning and discussion. Among students' self-constructed list of effective teaching characteristics, teachers' respect and care for the students ranks the first. Therefore, we can see that teachers' professional ethics and character are attached great importance to in U.S. College SETs. From the criteria of U.S. College SETs, we also see the student-centered teaching rationale and humanistic care, with an emphasis on teachers' respect for education and encouraging creativity in students.

Fourthly, U.S. colleges' emphasis on students' character education helps to raise the credibility of SETs.

U.S. college education emphasizes on the development of students' character and mind. First, in teacher hiring, U.S. colleges pay much attention to teachers' character, moral, and wisdom. Harry R. Lewis said in his book that the importance of teachers' character is drawing increasing attention [3]. For, teachers' character strength can exert great influence on students in teaching. No matter what quality of education they have received, the moment people pick up their college notes years later they would find that all has slipped their mind. It's easier for students to remember an excellent teacher than his course content. He also noted that the reason parents sent their kids to college is that they hope teachers' gracious and noble character can enlighten the kids [3]. College education turns out students of good character and only when such students participate in SETs, can the results be reliable and good.

Fifthly, the timings, methods and extent of the U.S. College SETs.

U.S. SETs are usually conducted in the first half of the term or at the term end. The first-half-term evaluation is to discover teaching problems, which helps students to give back their suggestions to teachers so as to improve teaching. Also it helps students to adjust their course selections. The term-end 
evaluation, which is in the last two weeks before finals, provides a comprehensive view of students' evaluation of teaching, teachers and opinions or suggestions for the course contents. There are many types of U.S. College SETs. The frequently adopted ones include: SET scales; written opinions of evaluation; student interviews and students exams. In practice, the systematic SET scales are used online. The extent of SETs involves almost all the students and all the courses except independent research and extra curriculum. Besides, on commencement ceremony, many top universities will invite the graduating seniors to vote for their most distinguished professor.

\section{Teaching and Learning}

\section{A. Develop General Educational Goals as Criteria for SETs}

SET seems to be a small link in school education. Especially when compared with the massive operating system of the whole school, SET can be easily ignored. However, teaching is the center of school education. Set in the links of teaching process, SET is the final evaluation of teachers' labor, the popularity of the course among students, teachers' credibility and reputation. If those evaluations are not scientific, they are bound to weaken teachers' teaching enthusiasm. So, how should College SETs be done? First, a comprehensive and clear set of general educational goals and objectives should be established. The main purpose of college education should not be the mere transition of some practical knowledge. The general educational objectives of world firstclass colleges focus on the ability to clearly and appropriately communicate in writing and speaking, critical thinking, students' moral sense and character, qualities of adapting to multi-cultures and globalization, how to arouse diverse academic interests in students and promote employment competence, which are all worth Chinese colleges' attention and learning. In this way, college education may pay attention to the maturity of students' mind and intelligence and turn out all-rounded talents who are equipped not only with solid specialized knowledge and general extensive learning but also with research, humanistic and moral qualities [6].

Secondly, having established clear educational goals, we also need to build up reasonable and scientific systems of specialized courses. The "depth and breadth combined curriculum model" is worth being drawn on. Nowadays, our country is advocating the issue of the inheritance of cultural heritage in all social realms, which is just the basic mission of college education. The content of cultural heritage should be represented in the general-knowledge education by providing introductory courses like Chinese History, History of Chinese Art, History of Chinese Economy, History of Chinese Science and Technology, History of Chinese Classical Literature, History of Chinese Modern Literature and Chinese Cultural Heritage and so on. College students should draw on nutrients of knowledge in the spiritual treasury of philosophy, literature, art, and history. Only being cultivated in this way, can our college students be able to do thinking on the development of the modern society, who should not be a technician but a designer.

At the same time, under the circumstances of globalization and competition, college curriculums must be multi-dimensional and capable of conducting dialogues with the world. The general-knowledge curriculum should also include courses about world and diverse civilizations for students to understand the route of world development. College should offer general-knowledge courses on world civilization history, history of world literature and world cultural heritage. Will Durant's The Story of Civilization can be called the chronicles of the $20^{\text {th }}$ century, which should be introduced into our general-knowledge courses. In the internet age, "internet + " model should also be woven into our curriculum.

Only when the clear general educational goals are set and the corresponding specialized course system is built up, will SETs have criteria and directions therefore to possess true practical implications.

\section{B. Cultivate Honesty and Credibility in Students' Character}

Character education appears not to be closely related to teaching evaluation, however, the two are greatly connected. For, all the assessments and evaluations are based on honesty, without which even the best criteria would amount to nothing. Talented students without moral senses can be harmful to the society. Socrates once said virtue equals to knowledge. Therefore, it shouldn't be ignored that college education should turn out students who have sound and strong senses of morality and responsibility and qualities of honesty and credibility. Bok Derek comments that if college education misled students, it's the whole nation that would taste the bitter fruit of it. Conversely, a society will benefit boundlessly, if college can teach students to express themselves accurately, think clearly, analyze problems rigorously, be morally sound, be sensitive to and opinionated on social issues [1].

The emphasis on students' character education is helpful for redirecting the utilitarian motives, casual attitudes, irrational factors and possible retaliations against teachers in SET to honest, credible and fair attitudes towards SET so as to increase the credibility of SET.

\section{Build up Student-Centered SET Criteria System}

At present, most Chinese higher education institutions are unable to lay down a complete and specific criteria system for SET, which leads to the possible misinformation of online evaluation from the very beginning. Although SET also emphasizes on teachers' class performance, it's still too general, like the fixed items about teaching style, teacher morality, teaching attitude, course content, teaching methods and teaching effectiveness.

The evaluation criteria of some colleges are divided into teacher evaluation and course evaluation, which appear to be specific, however, are not devised from students' perspective, therefore, don't quite fit. For instance, the criteria for the overall evaluation on teachers are listed as below: the curriculum design fits the needs of educational goals; course credits are reasonably awarded; rich course content; flexible 
learning methods; helpful for improving students' abilities and qualities; class organization helpful to achieve expected teaching results; reasonable course assessment methods and requirements; great gains from the course and so on. The overall evaluation on the course includes: reasonable teaching requirements and rich content; rich teaching resources helpful for learning; great gains from the course and great course value. In fact, curriculum design and credits award are the responsibilities of the teaching affairs' office, therefore, can't be the criteria for teacher evaluation. And the evaluation of course assessment methods is also beyond students' experience. In short, those SET criteria are not close to students' learning situations and lack humanistic care for students.

The purpose of education is to arouse interest and encourage creativity in students. Therefore, SET criteria should first pay attention to teachers' professional character that includes: teaching enthusiasm, respect and care for students, being ready to help and so on. Second, SET criteria should also emphasize on teachers' professional competence and knowledge of subject matters, like how to arouse students' interest, clarity and comprehensibility of lectures, adequate lesson preparation and good class organization and encouraging questioning and discussion etc.. So, it is of great importance to construct SET criteria from students' perspective, which are student-oriented, concise and easy to understand as well as applicable to all courses.

\section{Set up Specialized, Independent and Fair Third-Party SET Agencies and the Objective SET Results should be Connected to Teacher Promotion.}

Normally, SET is conducted by a department of school teaching affairs administration in Chinese colleges, whose function is to manage and monitor teachers' teaching quality. Thereforre, it's necessary to explore the model of third-party SET agencies that are specialized, independent and fair so that it can be entrusted to education experts to design a scientific, reasonable and humanistic SET criteria system without being influenced by personal relations.

SET agencies should be dedicated to exploring objective and fair evaluation methods and constructing effective SET systems. What's more, they should also communicate with teachers actively to give feedback. Meanwhile, the objective SET results should be taken into account in teacher promotion and payment rise. Newly recruited faculty should be informed that if they don't have any records of teaching effectiveness and students feedback, they won't be qualified or get promotion.

Education is the vital fountain of life for every country and nation. As the last part of the race, the value and significance of higher education should never be ignored. These quests are significant for enhancing the competitiveness and sustainability of Chinese colleges, like exploring the humanistic rationale in teaching practice, learning from the findings of the world education, researching on advanced SET theories, establishing scientific, reasonable, fair SET criteria systems to encourage both teachers' and students' enthusiasm and creativity and so on.

\section{Conclusion}

Students' evaluations of teaching (SETs) are rather popular and fairly matured in the U.S. higher education institutions, which have been equipped with an objective and reliable management system. This paper aims to explore the practice of SETs in U.S. colleges. Through comparative analysis, the paper tries to shed some light on the SETs in Chinese Higher Education from three perspectives, namely, rationale, method and management system. Finally, the research finds that Chinese colleges may learn from U.S. SETs from the following aspects: First, U.S. colleges have general educational goals; second, U.S. SETs emphasize on teachers' professional ethics and character; third, the independence and objectiveness of U.S. SETs are ensured by a third-party agency; fourth, there is a multi-dimensional and studentcentered evaluation criteria system in the U.S. SETs.

\section{References}

[1] D. Bok, Our Underachieving Colleges :A Candid Look at How Much Students Learn and Why They Should Be Learning More, $2^{\text {rd }}$ ed., East China Normal University Press, 2012, PP1-23.

[2] H. Rosovsky, The University: An Owner's Manual, Shandong people's publishing house, 1996, P240.

[3] H. R.Lewis, Excellence without A Soul: How A Great University Forgot Education, $2^{\text {rd }}$ ed., East China Normal University Press, 2012, PP11-102

[4] J.-C. Wu, M.-J. Wang, "The Importance of Students' Evaluation of Teaching Viewed from the Practice of American Universities," Journal of Jiangsu Polytechnic University, Vol.7, no.1, March 2006.

[5] L. Cao, "Brilliant quality of teaching in American universities-A study based on student evaluation," Journal of Hebei Normal University, Educational Science Edition, Vol.14, no.3, March 2012.

[6] J.-B. Yang, "Good researchers are Good teachers? A worldwide topic of higher education - on the "good" teacher evaluation criteria and realization of quality teaching," Education Science, Vol.29, no.6, December 2013. 